No. 4800 October 28,1961

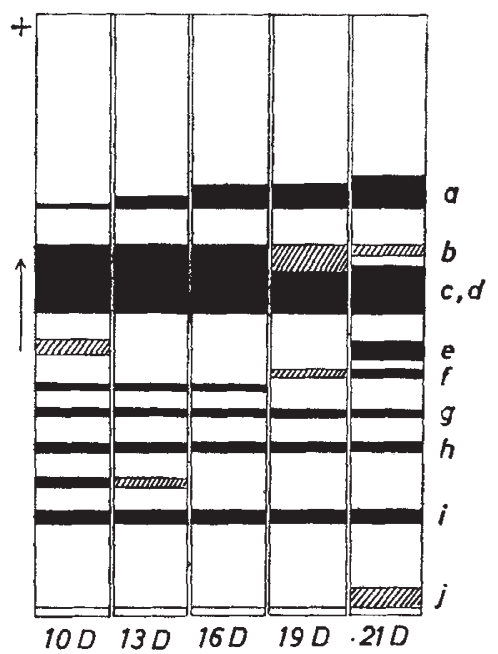

Fig. 1. A schematic representation of the starch-gel electrophoretic pattern of serum of the developing chicken embryo. The letters $a$ to $j$ refer to albumin and $\gamma$-globulin. The numbers $10,1316,19$ and 21 indicate the days of incubation. The striped bands represent the areas that could scarcely be distinguished on the original patterns

albumins) could be distinguished on the pattern from the 10-day old chicken embryo, of which at least seven components corresponded in mobility to those found in the day-old chick. The patterns from the sera of 13,16 , and 19 days of incubation also showed similarity in pattern to that of the day-old chick. A component present in the sera of the 10-day and 13-day old embryo and situated somewhere between components $h$ and $j$ of 21-day old embryo was not distinguishable in the sera of the older embryos. The results presented here indicate that apparently with the exception of $\gamma$-globulins and some other fractions, as demonstrated in Fig. 1, almost all other components present in the day-old chick are present in the serum of 10-day old embryo, as is revealed by the method of starch-gel electrophoresis, and that the transformation occurring throughout this period of development is apparently of a quantitative rather than qualitative nature.

Razi Institute,

A. Amin

Hessarak, Karaj, Iran.

1 Moore, D. H., Shen, S. C., and Alcxander, C. S., Proc. Soc. Exp. Biol. Med., 58, 307 (1945).

"Marshall, M. E., and Deutsch, H. F., J. Biol. Chem., 185, 155 (1950).

"Heim, W. G., and Schechtman, A. M., J. Biol. Chem., 209, 241 (1954).

+ Hradec, J,, and Lemez, L., Czechoslov. Morf., 2, 260 (1954).

- Vanstone, W. E., Maw, W. A., and Common, R. H., Canad. J. Bio. chem. Physiol., 33, 891 (1955).

- Amin, A., Nature, 191, 708 (1961).

7 Smithies, O., Biochem $J_{.,}$B1, 629 (1955).

${ }^{8}$ Smithies, O., Biochem. J., 71, 585 (1959).

- Amin, A., ana Korour, M., Embryologia, 7, 1 (1961).

\section{A Zinc-requiring Alkaline Phosphatase in the Ventral Lobe of the Rat Prostate}

ZINe has been shown to play an important part in the activity of phosphatases ${ }^{1-7}$. We have now found evidence for the existence of a zinc-dependent alkaline phosphatase in the ventral lobe of the rat prostate. The hydrolysis of $0.002 M$ adenosine monophosphate in $0.065 M$ tris-(hydroxymethyl)-amino methane buffer at $p \mathbf{H} \mathbf{9 . 4}$ by homogenates of the gland

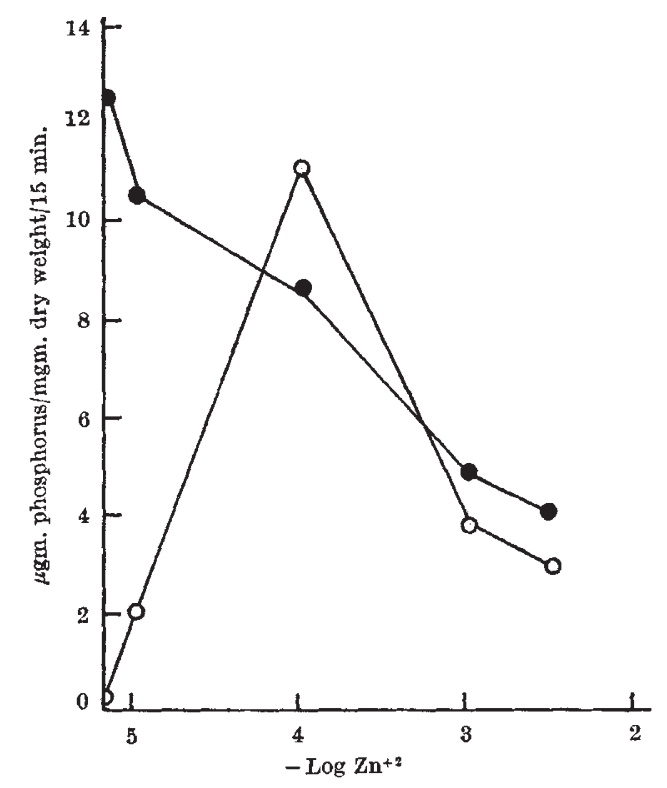

Fig. 1. Effect of zinc on the hydrolysis of adenosine monophosphate by prostatic homogenates from the rat ventral lobe. The effect of the addition of zine to a homogenate dialysed for $3 \mathrm{hr}$. against tris buffer at $p \mathrm{H} 7.0$ at $0^{\circ}$ ( ) and the addition of $10^{-3} M$ EDTA to the homogenate followed by dialysis for $3 \mathrm{hr}$. (O). Phosphatase activity was measured by the method of Fiske and tris buffer at $p$. $9.4,0.1 \mathrm{ml} .0 \cdot 04 M$ adenosine monophosphate, $0.9 \mathrm{ml}$. water, $0.5 \mathrm{ml}$. homogenate; the mixture was incubated for 15 min. at $37^{\circ}$

was progressively inhibited by increasing concentrations of zine (Fig. 1).

The addition of ethylenediamine tetraacetic acid (EDTA) at concentrations greater than $10^{-8} M$ to homogenates inhibited the phosphatase activity by $30-50$ per cent. When EDTA treatment was followed by dialysis against tris buffer at $p \mathrm{H} 7 \cdot 4$, the inhibition was practically 100 per cent.

The addition of zinc acetate restored the activity of the inhibited enzyme to about 80 per cent of its original value. Sodium acetate had no effect. After reactivation of the enzyme, increasing the concentration of zinc caused normal inhibition (Fig. 1).

In contrast to zine ions, magnesium and calcium ions reversed to a slight extent the inhibition caused by EDTA and dialysis. Since the logarithms of the stability constants for EDTA complexes of zine, calcium and magnesium are in the ratio $16 \cdot 3: 10 \cdot 6$ : 8.7 (ref. 8 ), the greater activity of zinc did not depend on the binding capacity of EDTA.

We wish to thank the British Empire Cancer Campaign for a grant to support the work.

\section{LEONORA HOPKINSON}

J. C. N. WAKELEYY

Department of Chemical Pathology, King's College Hospital, Denmark Hill, London, S.E.5.

'Cloetens, R., Biochem. Z., 308, 37; 310, 42 (1941).

${ }^{2}$ Abvers et al, Ber. dtsch. Chem. Ges., 71, 1913 (1988).

s Hove et al., $J$, Biol. Chem., 134, 425 (1940).

- Sadisvan, V., Nature, 169, 418; 170, 421 (1952).

- Kaye, M. A. C., Biochim. Biophys. Acta, 18, 456 (1955).

- Mathies, J. C., J. Biol. Chem., 233, 1121 (1958).

"Haurowitz, J., Amer. Chem. Soc. Abstr. of Papers, Meeting No. 126.

- Smith, R. L., The Sequestration of Metals (Chapman and Hall, Iondon).

'Fiske, C. H., and Subbarow, Y., J. Biol. Chem., 81, 629 (1929). 